\title{
Correction to: Dynamical Bulk Scaling Limit of Gaussian Unitary Ensembles and Stochastic Differential Equation Gaps
}

\author{
Yosuke Kawamoto $^{1} \cdot$ Hirofumi Osada $^{1}$ (D)
}

Received: 5 May 2019 / Published online: 24 May 2019

(C) The Author(s) 2019

\section{Correction to: J Theor Probab (2019) 32:907-933 https://doi.org/10.1007/s10959-018-0816-2}

The article Dynamical Bulk Scaling Limit of Gaussian Unitary Ensembles and Stochastic Differential Equation Gaps, written by Yosuke Kawamoto and Hirofumi Osada, was originally published electronically on the publisher's internet portal (currently SpringerLink) on 14 February 2018 without open access.

With the author(s)' decision to opt for Open Choice, the copyright of the article changed on 15 May 2019 to (C) The Author(s) 2019 and the article is forthwith distributed under the terms of the Creative Commons Attribution 4.0 International License (http://creativecommons.org/licenses/by/4.0/), which permits use, duplication, adaptation, distribution and reproduction in any medium or format, as long as you give appropriate credit to the original author(s) and the source, provide a link to the Creative Commons license and indicate if changes were made.

Open Access This article is distributed under the terms of the Creative Commons Attribution 4.0 International License (http://creativecommons.org/licenses/by/4.0/), which permits unrestricted use, distribution, and reproduction in any medium, provided you give appropriate credit to the original author(s) and the source, provide a link to the Creative Commons license, and indicate if changes were made.

Publisher's Note Springer Nature remains neutral with regard to jurisdictional claims in published maps and institutional affiliations.

The original article can be found online at https://doi.org/10.1007/s10959-018-0816-2.

Hirofumi Osada

osada@math.kyushu-u.ac.jp

Yosuke Kawamoto

y-kawamoto@math.kyushu-u.ac.jp

1 Faculty of Mathematics, Kyushu University, Fukuoka 819-0395, Japan 